\title{
Three-Year Exploitation Tests of a Photovoltaic Plant in a Zero-Energy Single-Family House under the Polish Conditions
}

\author{
Kazimierz Gaj' \\ 1 Department of Environment Protection Engineering, Wroclaw University of Science and Technology, \\ Wybrzeże Wyspiańskiego 27, 50-370 Wrocław, Poland \\ e-mail: kazimierz.gaj@pwr.edu.pl
}

\begin{abstract}
The subject of the study is the analysis of the energy self-sufficiency of a single-family house, equipped with an on-grid photovoltaic plant and electric heating system. The study is based on 3-year tests of a real plant located in southwestern Poland. The main aim of the research was to determine the conditions for full balancing of the energy produced and returned from the grid in relation to the legal system in Poland. The climate conditions and trends of their changes at the location of the house, as well as the impact of the angle of inclination and orientation of the modules on energy yield were analyzed. The annual and monthly balances of energy produced, fed into the electricity grid and consumed during the period of 2017-2019, were presented. The monthly and annual variability of generated energy was subject to statistical evaluation. The payback time and the value of the avoided $\mathrm{CO}_{2}$ emissions were calculated. The final effect of the research was to determine the energy, economic and ecological profits of the analyzed installation. It was shown that in the "net-metering" system in force in Poland, it is possible to fully cover the energy demand just by using solar energy, and the reimbursement for a photovoltaic plant will take place after approx. 8 or 12 years, depending on the electricity tariff chosen.
\end{abstract}

Keywords: zero-energy house, solar energy, photovoltaics, accumulative electric heating, balance sheet, payback time

\section{INTRODUCTION}

In the era of eliminating the energy based on fossil fuels and solid biomass due to the climate and smog threats, there seems to be no alternative to the zero-energy construction. The energy self-sufficiency effect of a single-family house can be achieved by using solar energy to power a heat pomp or electric heating. The latter case has been analyzed in this article. Considering the ever-increasing costs of grid electricity, the rapidly falling prices of solar plants, and the increasing number of sunny hours in Poland in recent years, photovoltaics has become the most promising direction for the development of distributed prosumer energetics under the Polish conditions. In Poland, in the years 1996-2016, the prices of photovoltaic modules dropped almost 10 times [Niechaj, 2016] and the installed capacity of photovoltaic plants as of 1.05.2020, according to the data from Polish Power Grids, amounted to $1833 \mathrm{MW}$, showing an increase of $181 \% \mathrm{y} / \mathrm{y}$.

Accumulation electric heating is distinguished by low investment costs and a practical lack of maintenance costs. In addition, it is characterized by moderate energy charges if it is accounted for under a dual-zone tariff-G12. It does not require a boiler or the construction of a heat distribution system, but only the purchase of the heating cables and their sinking in a slightly thicker than standard concrete underfloor screed, and/ or the purchase of relatively cheap free-standing accumulation furnaces. This study concerns such a heating system, which cooperates with an ongrid roof photovoltaic plant (hereinafter referred to as PV plant), i.e. releasing the surpluses of the produced energy to the electric grid, which are then retaken during the heating period. In addition, solar collectors are used to heat water. In accordance with the Polish Renewable Energy Act 
[Act, 2020], for the installations with an installed capacity $\leq 10 \mathrm{~kW}$, to which this study relates, for 1 $\mathrm{kWh}$ fed into the electricity grid, $0.8 \mathrm{kWh}$ can be retaken without any charge. The energy fed into the grid is billed not earlier than 12 months before the date of its introduction. The unused surplus can be used within the next 12 months, and if this does not happen, the seller has it for free.

Three years of operational experience of a typical single-family house located in south-west Poland (Fig. 1) showed that its energy self-sufficiency with the use of the energy and heat of solar radiation is possible - taking into account the legal conditions set out above.

The main aim of the study was to establish the conditions for achieving energy self-sufficiency, as well as to determine energy balances in relation to individual months and the years 2017-2019.

\section{CLIMATIC CONDITIONS}

The climate parameters affecting the efficiency of electricity production by a PV plant, in addition to insolation (Figs. 1-3, 5), include:

- temperature (Fig. 6), the increase of which causes an increase in resistance, resulting in a linear voltage drop, and thus a decrease in the cell efficiency [Adeeb et al., 2019; Rabczak \& Proszak-Miąsik, 2020];

- wind speed-affecting the intensity of heat exchange, and thus the temperature of the cell;

- atmospheric precipitation and humidity-causing the dispersing, absorbing, or blocking of solar radiation, but also the cleaning of the surface of modules.

Important arguments for the development of solar energy in Poland are:

- the increase in insolation observed in recent years (Fig. 2);

- the increase in the daily sunshine duration by over $1 \mathrm{~h} / \mathrm{d}$ in 20 years (Fig. 3);

- the decrease in the number of days with snowfall (Fig. 4).

The location of the analyzed building, due to the relatively high annual solar-radiation and moderate temperatures (Fig. 6), can be considered favorable from the point of view of photovoltaics. However, seasonal unevenness is a problem, because around $80 \%$ of total annual irradiation occurs between April and October (Fig. 5).

Other data affecting the energy yield in the area of the building location are collected in Table 1.

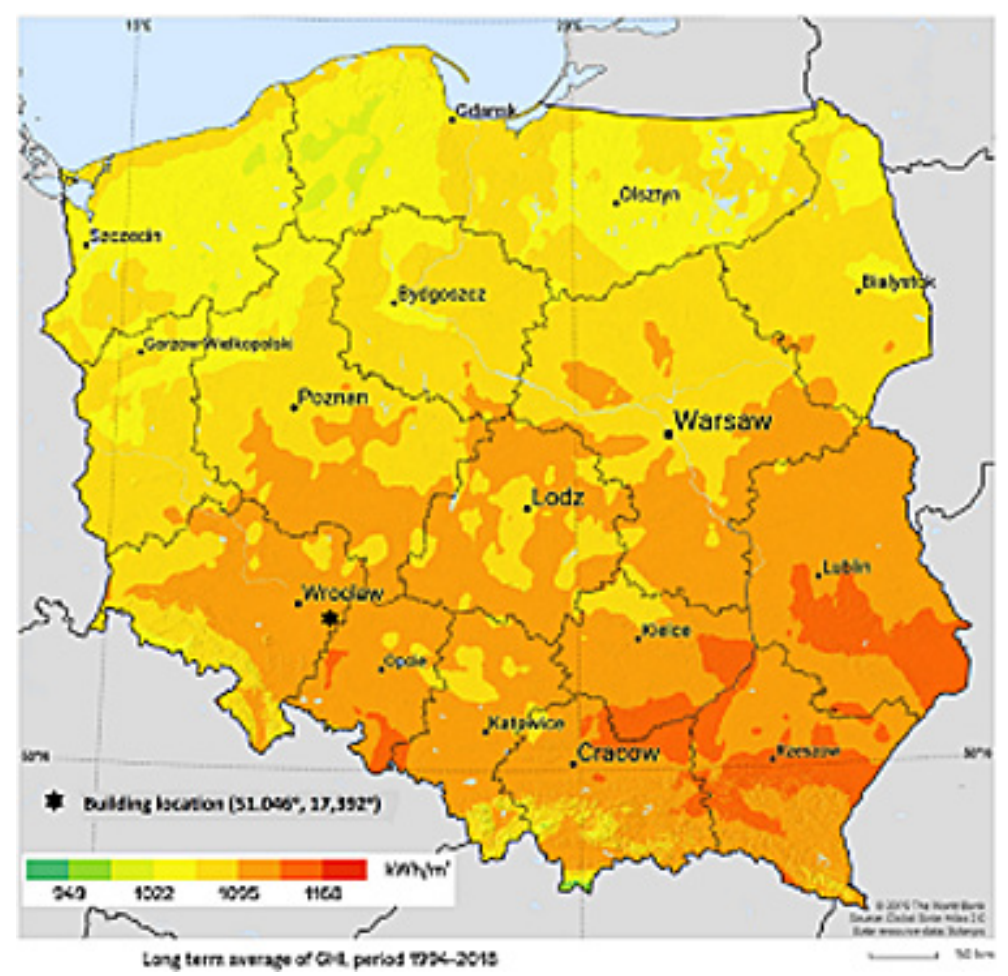

Fig. 1. Map of the average annual global horizontal irradiance (GHI) in Poland, compiled according to [SolarGIS, 2020] 


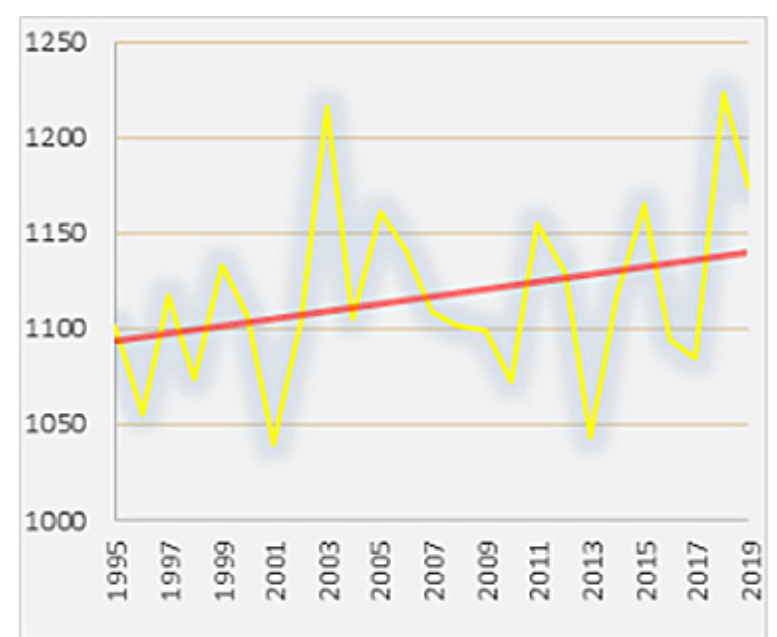

Fig. 2. Insolation trend in Poland $\left[\mathrm{kWh} / \mathrm{m}^{2}\right]$, developed according to [WeatherOnline, 2020]

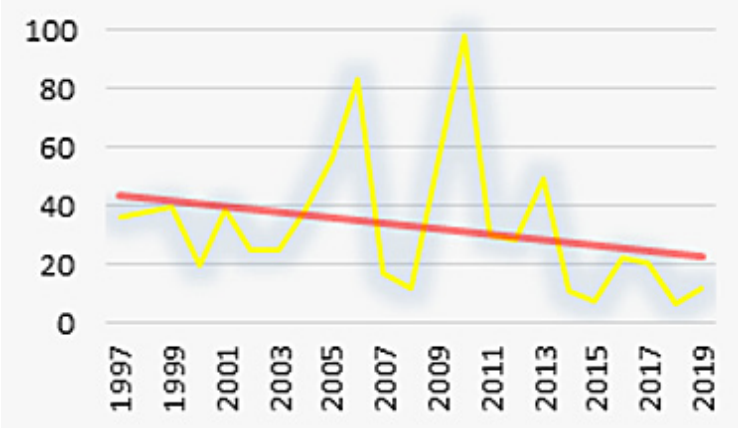

Fig. 4. Trend in the number of days with snowfall for the building location region, based on data [WeatherOnline, 2020]

\section{INFLUENCE OF THE ORIENTATION AND ANGLE OF INCLINATION OF MODULES ON THE EFFICIENCY OF A PHOTOVOLTAIC PLANT}

The optimal direction of the module decline, regardless of latitude, is south, with an acceptable deviation to the east or west of $\pm 45^{\circ}$, which does not significantly affect the annual performance (Fig. 7). According to Szymański [2013], with a $30^{\circ}$ deviation from the south, the change in energy yield during a year is about $2 \%$, and with a $60^{\circ}$ deviation - about $8 \%{ }^{1}$. For the angle of inclination of modules, this issue is less unequivocal. Due to the seasonal variation of the angle of incidence of sunlight, its optimum depends strictly on the geographical location. For Poland, in the case of the plants operating throughout the whole year, it is assumed that it should be in the range

${ }^{1}$ Data for $30^{\circ}$ module angle.

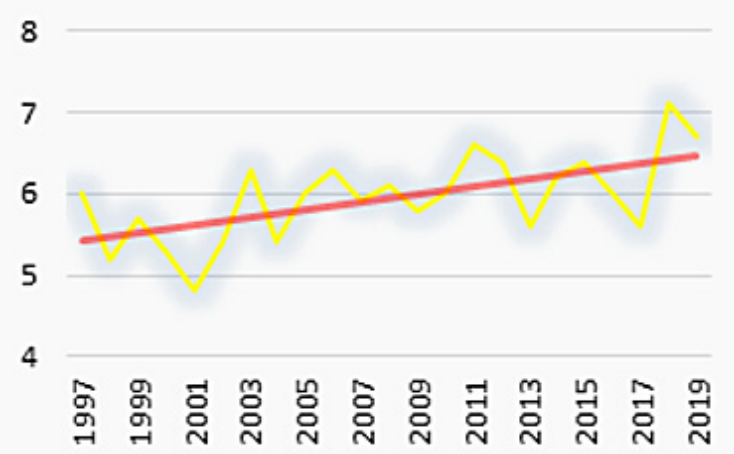

Fig. 3. Trend of the average annual number of sunny hours per day for the building location region, based on data [SolarGIS, 2020]

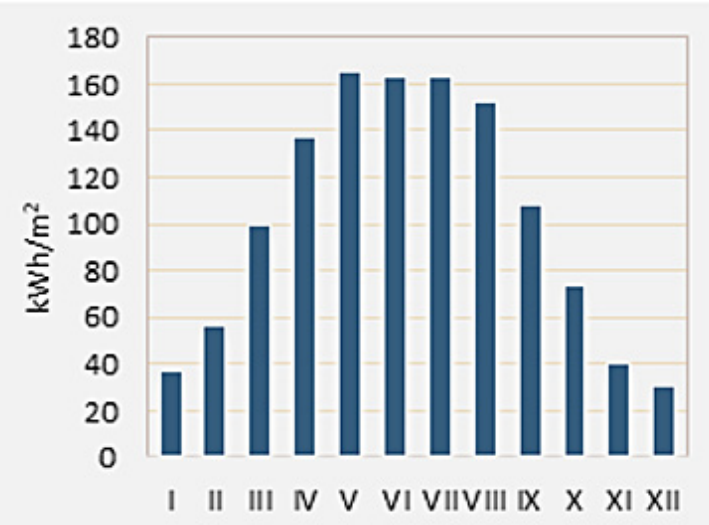

Fig. 5. Irradiation distribution on an inclined surface $\left(32^{\circ}\right)$, calculated with the model [SolarGIS, 2020] for the building location region

of $30-40^{\circ}$, with some authors pointing to an angle closer to the lower limit of the above range as more favorable [Baran, et al, 2013, Łotocki, 2013]. For example, the authors [Baran et al., 2013] indicate an angle of inclination of $27^{\circ}$ as optimal for Wroclaw, i.e. ensuring the maximum energy yield per year. Similar values for southern Poland were obtained by Szymański [2013] $-30-35^{\circ}$ (Fig. 8). According to the author, for this range there is the highest percentage increase in energy yield in relation to the yield for the angle $0^{\circ}-113 \%$. An additional aspect taken into account when choosing the slope of the modules may be their self-clearing, i.e. spontaneous sliding of the snow layer from the smooth surface of the module [Andrews et al., 2013]. However, in the era of global warming, this feature can be seen to be negligible for the considered location of the building (Fig. 3). 


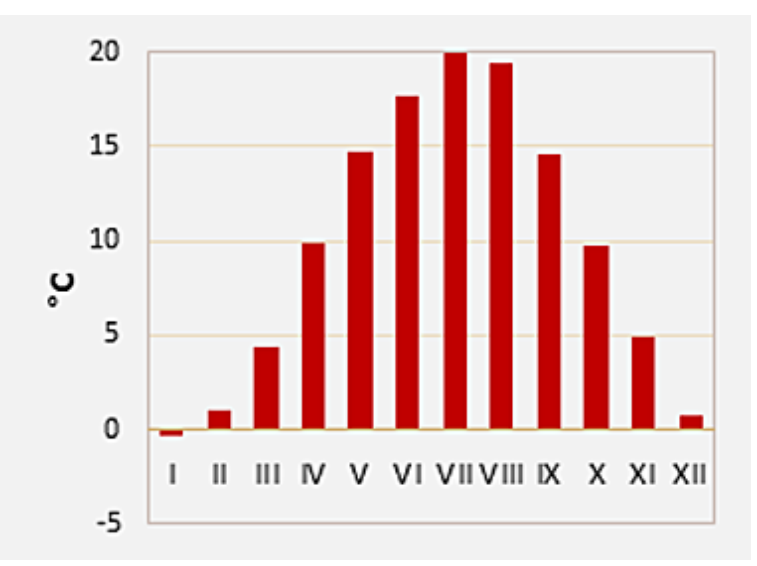

Fig. 6. Distribution of the average temperature at a level of $2 \mathrm{~m}$ above ground, calculated by the model

[SolarGIS, 2020] for the building location region

\section{CHARACTERISTICS OF THE ANALYZED HOUSE}

The tests were carried out for a detached single-family house with a usable attic (Fig. 9). The building has a roof with a slope of $32^{\circ}$ and a direction of decline $-\mathrm{SW}\left(227^{\circ}\right)$. It is made in a brick technology from silicate blocks insulated with mineral wool. The roof was covered with black cement tiles. The living room with glazing was placed on the SW side and the utility rooms-on the NE side. The design data of the building, relevant from the point of view of heat balance, are collected in Table 2.

Electric heating was installed as the primary heat source. Accumulation floor heating was used on the ground floor, and accumulation electric stoves in the attic. The water is heated using solar collectors. The parameters of the heating installations are collected in Table 3, and the basic data of the PV plant - in Table 4.

Table 1. Averaged climatic data for the building location region calculated by the model [SolarGIS, 2020], averaging period: 1994-2019

\begin{tabular}{|l|c|}
\hline Global horizontal irradiation & $1116 \mathrm{kWh} / \mathrm{m}^{2}$ \\
\hline Global tilted irradiation $\left(32^{\circ}\right)$ & $1227 \mathrm{kWh} / \mathrm{m}^{2}$ \\
\hline $\begin{array}{l}\text { Air temperature }-2 \mathrm{~m} \text { above ground } \\
\text { level }\end{array}$ & $9.7^{\circ} \mathrm{C}$ \\
\hline Wind speed - $10 \mathrm{~m}$ above ground level & $3.9 \mathrm{~m} / \mathrm{s}$ \\
\hline $\begin{array}{l}\text { Relative humidity }-2 \mathrm{~m} \text { above ground } \\
\text { level }\end{array}$ & $77 \%$ \\
\hline Precipitation & $578 \mathrm{~mm}$ \\
\hline
\end{tabular}

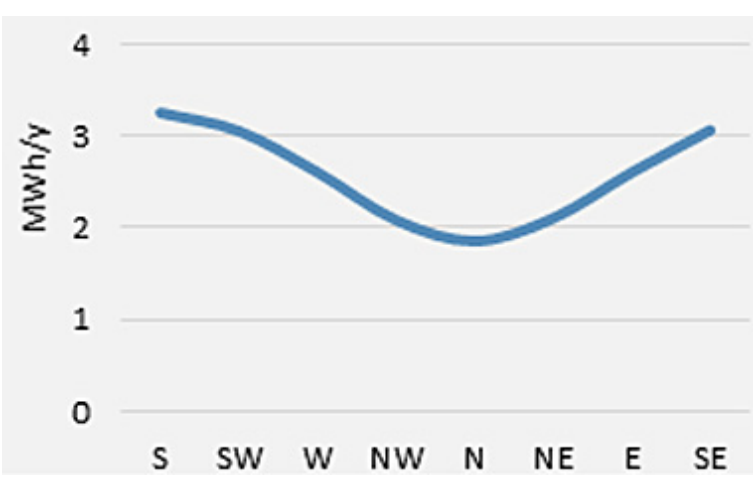

Fig. 7. Impact of panel orientation on the average annual electricity production for a $3.5 \mathrm{kWp}^{1}$ plant with polycrystalline modules, based on data

[Mirowski \& Sornek, 2015]

\section{Power determined in standardized laboratory conditions (STC): solar irradiance $1000 \mathrm{~W} / \mathrm{m}^{2}$, cell temperature $25{ }^{\circ} \mathrm{C}$, wind speed $0.0 \mathrm{~m} / \mathrm{s}$, at a reference air mass spectrum 1.5. \\ ENERGY EFFECTS AND STATISTICAL ANALYSIS OF THEIR VARIABILITY}

The results of the electricity balance calculations, averaged over 3 years, are presented in Table 5, the comparison of balances for individual years from 2017-2019 - in Fig. 10, and balances for individual months and years - in Fig. 11 and 12.

Electricity production in individual years can be considered stable and consistent with the value forecast by the SolarGIS model for the local conditions (maximum deviation of $10 \%$ ). The variability of annual electricity production is a simple function of the variability of insolation in individual years (according to Fig. 3).

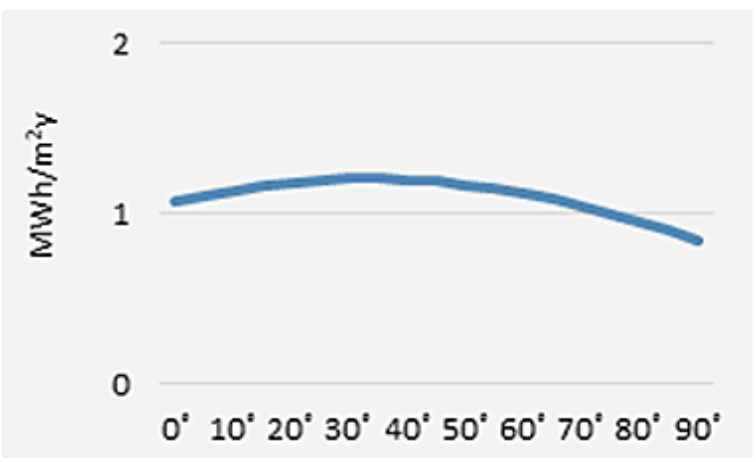

Fig. 8. Impact of the panel inclination angle on insolation for southern Poland, based on data [Szymański, 2013] 


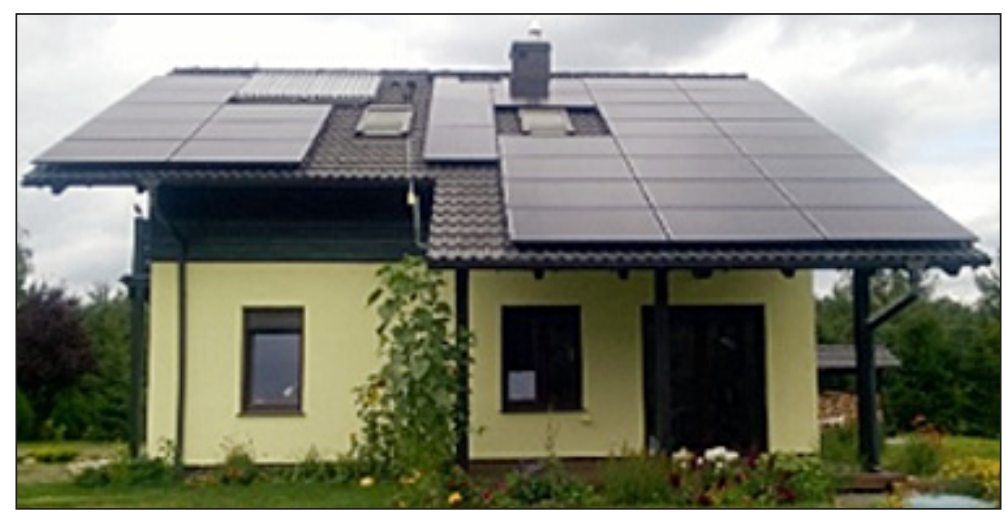

Fig. 9. View of the analyzed house from the SW side

Figure 11 shows the characteristic mismatch between the electricity production maxima and the electricity consumption maxima per year. In the non-heating periods, the distribution network mainly serves as an energy accumulator.

The surpluses of the produced energy over consumed energy occur from April to October, when $80 \%$ of the total annual energy is generated. In the remaining months, the energy consumed definitely exceeds the production. The deficit is compensated by the energy "accumulated" in the distribution grid.

The distribution of electricity generated in relation to the average monthly values in the years 2017-2019 (Table 6) was assessed using a relative deviation from the average value (Table 7):

$$
D_{\text {rel }}=\frac{\left(E_{r i}-E_{a v i}\right) \cdot 100 \%}{E_{a v i}}
$$

Table 2. The selected building parameters affecting the heat balance

\begin{tabular}{|l|l|}
\hline Cubature to be heated & $394 \mathrm{~m}^{3}$ \\
\hline Usable area of heated rooms & $124 \mathrm{~m}^{2}$ \\
\hline Wall insulation & Mineral wool blocks, $15 \mathrm{~cm}$ thick \\
\hline Roof insulation & $\begin{array}{l}\text { Mineral wool boards }(15 \mathrm{~cm} \text { thick) and OSB boards from the } \\
\text { inside }\end{array}$ \\
\hline Heat transfer coefficient of external walls and roof & $0.27 \mathrm{~W} / \mathrm{m}^{2} \mathrm{~K}$ \\
\hline Floor insulation on the ground & Extruded polystyrene boards, $8 \mathrm{~cm}$ thick \\
\hline Heat transfer coefficient of the floor on the ground & $0.33 \mathrm{~W} / \mathrm{m}^{2} \mathrm{~K}$ \\
\hline Window joinery & $\begin{array}{l}\text { Double-layer windows }\left(\mathrm{U}=1.0 \mathrm{~W} / \mathrm{m}^{2} \mathrm{~K}, 5 \text {-chamber profiles }\right. \\
\left(\mathrm{U}=1.3 \mathrm{~W} / \mathrm{m}^{2} \mathrm{~K}\right) \text { and external roller shutters }\end{array}$ \\
\hline
\end{tabular}

Table 3. Technical characteristics of the heating installations

\begin{tabular}{|l|l|}
\hline \multicolumn{2}{|c|}{ Ground floor - electric, floor accumulative heating } \\
\hline Heating system & Single core heating cables with screen $(20 \mathrm{~W} / \mathrm{m})$ \\
\hline Total power of heating cables & $5925 \mathrm{~W}$ \\
\hline Heat accumulator & Concrete screed $(11 \mathrm{~cm}$ thick) and terracotta \\
\hline \multicolumn{2}{|c|}{ Attic - electric storage stoves and floor heating mat in the bathroom } \\
\hline Type of ovens & With dynamic discharge \\
\hline Oven power & $3 \times 2000 \mathrm{~W}$ \\
\hline Heating mat power & $750 \mathrm{~W}\left(150 \mathrm{~W} / \mathrm{m}^{2}\right)$ \\
\hline \multicolumn{2}{|c|}{ Solar collectors } \\
\hline Type & Vacuum-tube \\
\hline Number of modules, active surface & 2 pcs., $3.86 \mathrm{~m}^{2}$ \\
\hline Hot water buffer tank & 2 -coil, $300 \mathrm{dm}^{3}$ \\
\hline Reserve electric heater power & $2000 \mathrm{~W}$ \\
\hline
\end{tabular}


Table 4. Parameters of the PV plant

\begin{tabular}{|l|l|}
\hline Total rated power & $9735 \mathrm{Wp}$ \\
\hline Module type & Monocrystalline (60 cells) \\
\hline Module rated power and efficiency & $33 \times 295 \mathrm{Wp}, 17.7 \%$ \\
\hline Inverter & $\begin{array}{l}\text { Three-phase, maximum power DC } 10250 \mathrm{~W}, \text { maximum } \\
\text { input voltage: } 1000 \mathrm{~V}\end{array}$ \\
\hline Annual yield forecast by the SolarGIS model [11] & $9569 \mathrm{kWh}$ \\
\hline Specific annual yield according to the model as above & $983 \mathrm{kWh} / \mathrm{kWp}$ \\
\hline Launch Date & 16.09 .2016 \\
\hline
\end{tabular}

Table 5. Averaged electricity balances for the period 2017-2019

\begin{tabular}{|l|c|}
\hline Average annual electricity production $\left(\mathrm{E}_{\mathrm{P}}\right)$ & $10073 \mathrm{kWh}$ \\
\hline The average annual amount of energy fed into the electricity grid $\left(\mathrm{E}_{\mathrm{F}}\right)$ & $8900 \mathrm{kWh}$ \\
\hline Average annual amount of energy taken from the electricity grid $\left(\mathrm{E}_{\mathrm{T}}\right)$ & $7843 \mathrm{kWh}$ \\
\hline Average annual electricity consumption $\left(\mathrm{E}_{\mathrm{C}}\right)$ & $9016 \mathrm{kWh}$ \\
\hline Average $\mathrm{E}_{\mathrm{T}} / \mathrm{E}_{\mathrm{F}}$ ratio in relation to the terms of the RES Act [1] & 0.88 \\
\hline Average electricity consumption indicator per $1 \mathrm{~m}^{3}$ of heated cubature of the house & $23 \mathrm{kWh} / \mathrm{m}^{3} \mathrm{y}$ \\
\hline
\end{tabular}

The mean value of absolute deviations from the average value $\left(\mathrm{D}_{\text {abs }}\right)$ was also determined:

$$
D_{a b s}=\frac{1}{12} \sum_{i=1}^{12}\left|E_{r i}-E_{a v i}\right|
$$

where: $i$ - subsequent months, $\mathrm{E}_{\text {avi }}$ - the average value of energy produced in month " $i$ " in a period of 2017-2019,

$E_{r i}$ - the real value of energy produced in the month "i" of the year.

It is a frequently used measure of data set variability, illustrating the concentration of real values around an average value. The smallest

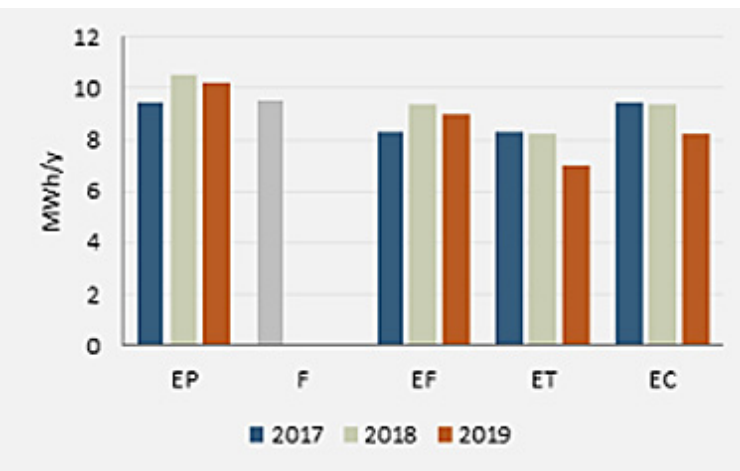

Fig. 10. Annual electricity balances for 2017-2019

EP - Energy generated, F - Generation forecast by the model [SolarGIS, 2020], EF - Energy fed into the electricity grid,

ET - Energy taken from the electricity grid, EC Energy consumed absolute deviation from the monthly average was recorded in June $2017-4.6 \mathrm{kWh}$, which is $0.3 \%$ of the average for this month, and the highest in April $2017-252.7 \mathrm{kWh}$, which is $22 \%$ of the average (Table 8).

The $\mathrm{D}_{\text {abs }}$ values for 2017, 2018 and 2019 were respectively: 93.3, 94.5, 66.7 kWh.

Annual deviation of the energy production value from the average annual value for the years mentioned above can be assessed as insignificant. It amounted to $-6.2 \%, 4.8 \%$ and $1.3 \%$, respectively.

The results of the statistical evaluation showed the stability of annual energy production, despite significant deviations in some months, especially in XII, I, II - Table 7 (e.g. up to approx. $40 \%$ in January 2017).

\section{ENVIRONMENTAL EFFECT}

The environmental effect of the PV plant was estimated on the example of the avoided $\mathrm{CO}_{2}$ emissions by the end user of electricity in Poland. According to [KOBiZE, 2019], the $\mathrm{CO}_{2}$ emission factor for such users, according to the data for 2018 , is $765 \mathrm{~kg} / \mathrm{MWh}$. It takes into account all electricity produced, regardless of the type of plant, i.e. installations for the combustion of fossil fuels and RES, as well as the losses during the distribution of electricity. The avoided emissions in 2017-2019 averaged about $7.7 \mathrm{Mg} \mathrm{CO}_{2} / \mathrm{y}$. 
a)

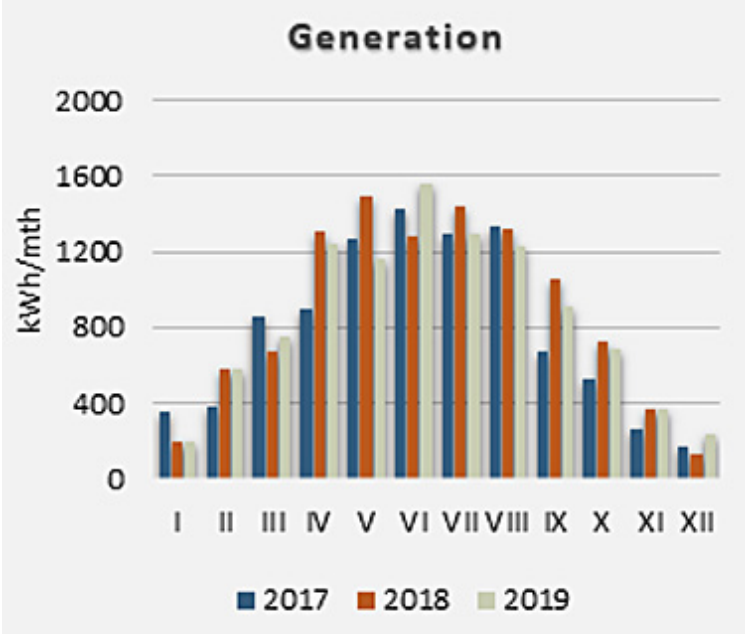

b)

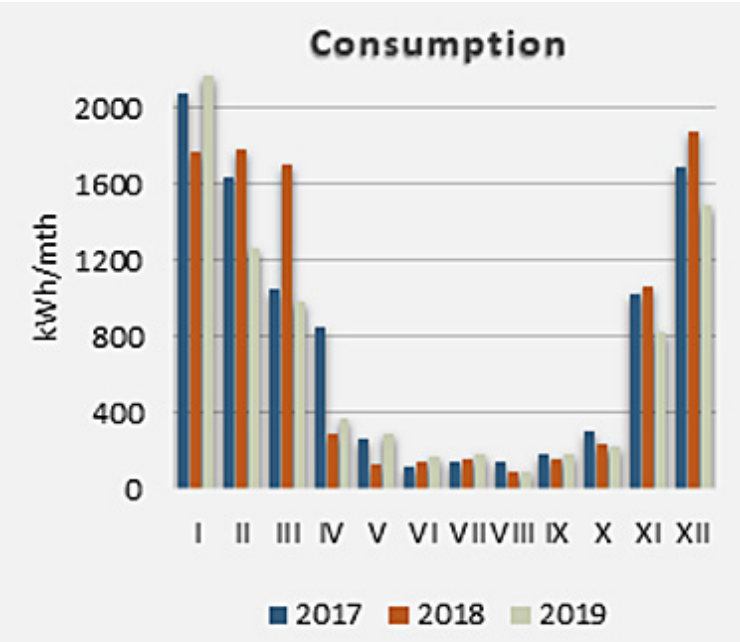

Fig. 11. Monthly balances of electricity production and consumption

a)

Annual balance $2017, \mathrm{kWh}$
ET / EF $=1.00$

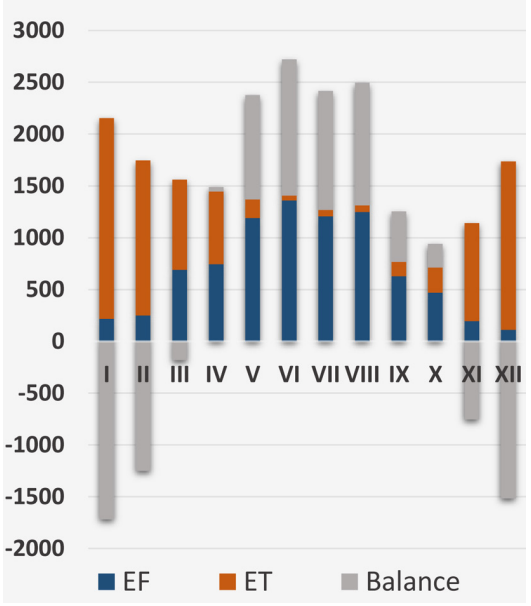

b)

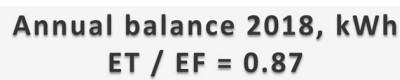

c)

\section{Annual balance 2019, kWh $E T / E F=0.78$}
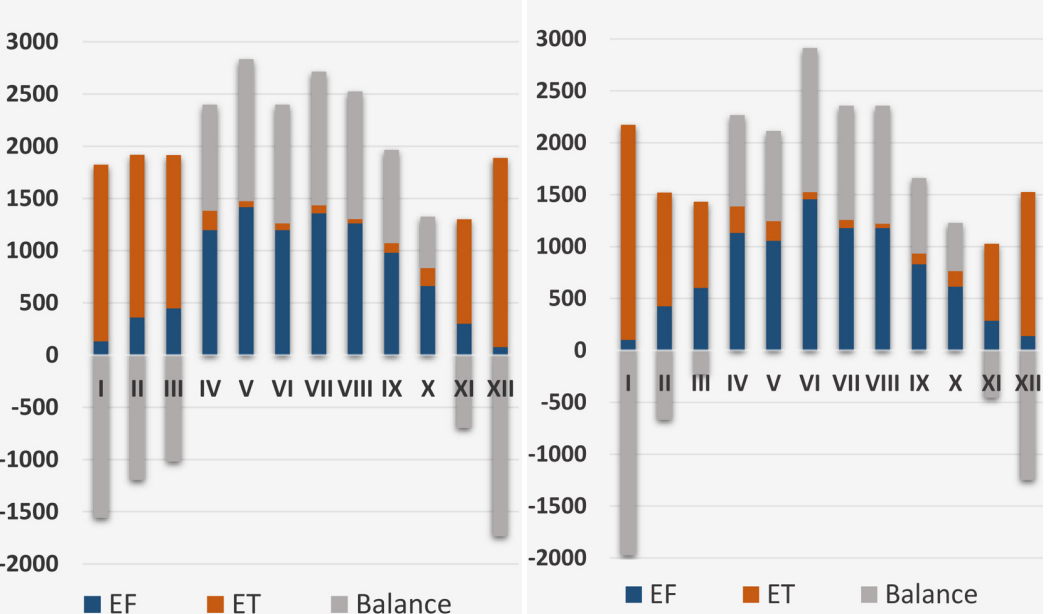

Fig. 12. Annual energy balances broken down into individual months for 2017-2019

Table 6. The average monthly values of energy produced in 2017-2019

\begin{tabular}{|c|c|c|c|c|c|c|c|c|c|c|c|c|}
\hline Month & $\mathrm{I}$ & $\mathrm{II}$ & $\mathrm{III}$ & $\mathrm{IV}$ & $\mathrm{V}$ & $\mathrm{VI}$ & $\mathrm{VII}$ & $\mathrm{VIII}$ & $\mathrm{IX}$ & $\mathrm{X}$ & $\mathrm{XI}$ & $\mathrm{XII}$ \\
\hline $\begin{array}{c}\text { Average } \\
\text { production } \\
\left(\mathrm{E}_{\text {avi }}\right) \cdot \mathrm{kWh}\end{array}$ & 251.0 & 516.0 & 761.2 & 1146.4 & 1309.0 & 1424.8 & 1339.6 & 1289.8 & 878.6 & 644.6 & 333.5 & 178.9 \\
\hline
\end{tabular}

Table 7. Relative deviation from the average value $\left(\mathrm{D}_{\text {rel }}\right), \%$

\begin{tabular}{|c|c|c|c|c|c|c|c|c|c|c|c|c|}
\hline Year/month & $\mathrm{I}$ & $\mathrm{II}$ & $\mathrm{III}$ & $\mathrm{IV}$ & $\mathrm{V}$ & $\mathrm{VI}$ & $\mathrm{VII}$ & $\mathrm{VIII}$ & $\mathrm{IX}$ & $\mathrm{X}$ & $\mathrm{XI}$ & $\mathrm{XII}$ \\
\hline 2017 & 41.8 & -26.0 & 13.1 & -22.0 & -2.8 & 0.3 & -3.7 & 2.98 & -23.3 & -18.8 & -19.9 & -3.6 \\
\hline 2018 & -19.1 & 12.8 & -11.4 & 13.5 & 14.1 & -9.9 & 7.6 & 1.9 & 19.7 & 11.9 & 8.9 & -26.5 \\
\hline 2019 & -22.7 & 13.2 & -1.7 & 8.5 & 11.3 & 9.5 & -3.8 & -4.9 & 3.6 & 6.8 & 11.0 & 30.0 \\
\hline
\end{tabular}

Table 8. Absolute deviation from the average value $\left|\mathrm{E}_{\mathrm{avi}}-\mathrm{E}_{\mathrm{ri}}\right|, \mathrm{kWh}$

\begin{tabular}{|c|c|c|c|c|c|c|c|c|c|c|c|c|}
\hline Year/month & I & II & III & IV & V & VI & VII & VIII & IX & X & XI & XII \\
\hline 2017 & 104.91 & 134.24 & 99.94 & 252.72 & 36.57 & 4.61 & 49.76 & 38.47 & 204.31 & 121.04 & 66.22 & 6.43 \\
\hline 2018 & 47.87 & 66.24 & 87.02 & 154.81 & 184.92 & 140.47 & 101.19 & 24.46 & 172.72 & 76.98 & 29.53 & 47.33 \\
\hline 2019 & 57.03 & 68.00 & 12.91 & 97.91 & 148.36 & 135.87 & 51.44 & 62.94 & 31.59 & 44.06 & 36.68 & 63.76 \\
\hline
\end{tabular}




\section{FINANCIAL EFFECT}

In order to assess the profitability of the PV plant, the PBT (Pay Back Time) indicator was used. This indicator specifies the time needed to recover the investment costs:

$$
P B T=\frac{K-P}{\frac{\left[0.8 \cdot E_{F}+\left(E_{P}-E_{F}\right)\right] \cdot k \cdot \sum_{1}^{25}(1.03)^{j-1}}{25}}
$$

where: $K$ - gross PV plant cost, $14640 \mathrm{EUR}^{2}$;

$P$ - donation, 1100 EUR (acc. to the current Polish government program "My electricity");

$E_{P}, E_{F}-$ according to Table 5;

$E_{P}-E_{F}$ - average annual amount of electricity produced and directly consumed, $1173 \mathrm{kWh} / \mathrm{y}$;

0.8 - "return" factor (for $1 \mathrm{kWh}$ fed into the network, the prosumer can retake 0.8 $\mathrm{kWh}$ - in accordance with [Act, 2020]);

$k$ - gross unit price of electricity, including distribution costs for individual customers in 2017, for the G11 tariff -0.12 EUR/kWh and for the G12 tariff (night zone / day zone: $70 / 30 \%$ ) -0.09 EUR/ $\mathrm{kWh}$;

$j$-subsequent year of operation.

An annual increase in the electricity and distribution prices of $3 \%$, and a 25 year lifetime of the plant were adopted. The assessment was carried out for 1-zone (G11) and 2-zone (G12) tariffs, assuming in the second case that $70 \%$ of energy is consumed in the reduced "night" zone. The costs of the energy drawn from the grid by the inverter (self-consumption at night $-1 \mathrm{~W}$ ) and the costs of cleaning the panels (in the analyzed period there was no need to wash the panels) were omitted.

On the basis of the PBT indicator defined above and the adopted assumptions, it can be predicted that the investment will pay back after 8.6 years for the G11 tariff, and after 12.1 years for the G12 tariff.

Taking into account the "return ratio" of 0.8 [Act, 2020], an annual energy balance close to zero was obtained, which allowed the charges for grid electricity to be minimized (or their practical absence in 2019, apart from minor distribution fees - approx. $3 \mathrm{EUR} / \mathrm{mth}$ ).

\footnotetext{
${ }^{2}$ According to the exchange rate of 12.05 .2020 (4.55 PLN/EUR)
}

\section{CONCLUSIONS}

1. The analysis of the climatic conditions at the location of the examined house showed that due to relatively high insolation, moderate temperatures and mild winters, there are favorable conditions for the development of photovoltaics.

2. The presented results of the PV plant's operational tests for the assumed heating system showed that - in the "net-metering" system implemented in Poland - it is possible to fully cover the energy demand of a single-family house by only using solar energy.

3. The obtained ratio of the energy taken from the electricity grid to the energy supplied by the PV plant of slightly less than one (0.78-1.00) confirmed the correctness of the adopted design assumptions and showed that it is possible to balance the energy taken and exported. In the analyzed 3-year period, the fees for energy consumption and distribution were negligible.

4. The achieved energy effects of the analyzed PV plant prove the high stability of annual production. The largest percentage deviations from the monthly average occurred in the winter months, which, due to the scale of energy production in these months, is of no practical importance.

5. The obtained results confirm that with the correct selection of the PV plant power in relation to energy demand and with the rational use of the installation by a prosumer (e.g. maximizing reception during electricity generation), it is possible to return the expenditure incurred after 8.6 or 12.1 years-depending on the type of electricity tariff used-i.e. in less than half of the expected lifetime of the plant.

6 . The use of solar energy for heating purposes in the analyzed system can be an attractive way to cover the heat demand in a single-family house under the Polish conditions, both in the economic and ecological terms (avoided $\mathrm{CO}_{2}$ emissions over the entire assumed lifetime can be estimated at almost $200 \mathrm{Mg}$ ).

\section{Acknowledgements}

This paper was co-financed within the "Excellent Science" program of the Polish Ministry of Science and Higher Education.

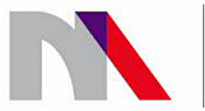
Ministry of Science and Higher Education Republic of Poland 


\section{REFERENCES}

1. Act on renewable energy sources - Announcement of the Speaker of the Sejm of the Republic of Poland of 9 January 2020 (in Polish). Journal of Laws, item 261.

2. Adeeb J., Farhan A., Al-Salaymeh A. 2019. Temperature effect on performance of different solar cell technologies. Journal of Ecological Engineering, 20(5), 249-254.

3. Andrews R.W., Pollard A., Pearce J.M. 2013. The effects of snowfall on solar photovoltaic performance. Solar Energy, 92, 84-97.

4. Baran K., Leśko M., Wachta H. 2013. Research on the positioning of solar panels on Polish territory (in Polish), PAK, 59(10), 1097-1100.

5. KOBiZE (National Center for Emissions Balancing and Management), 2019. $\mathrm{CO}_{2}, \mathrm{SO}_{2}, \mathrm{NO}_{x}, \mathrm{CO}$ and total dust emission ratios for electricity based on information contained in the National Database of Greenhouse Gas Emissions and Other Substances for 2018 (in Polish), IOŚ-PIB, Warsaw, Poland.

6. Łotocki H. 2013. ABC of photovoltaic systems coupled to the power grid (in Polish). Publishing house KaBe, Krosno, Poland.

7. Mirowski T., Sornek K. 2015. The potential of prosumer energy in Poland on the example of photovoltaic micro installations in individual construction (in Polish). Energy Policy Journal, 18(2), 73-84.

8. Niechaj M. 2016. Effective use of photovoltaic systems in polish conditions, Journal of Ecological Engineering, 17(5), 147-154.

9. Rabczak S., Proszak-Miąsik D. 2020. Analysis of Energy Yields from Selected Types of Photovoltaic Panels, Journal of Ecological Engineering, 21(1), 20-28.

10. SolarGIS, https://solargis.com/maps-and-gis-data/ download/poland, accessed on 20 April 2020.

11. Szymański B. 2013. Small photovoltaic installation (in Polish), Globenergia, Kraków.

12. WeatherOnline. https://www.weatheronline.pl, accessed on 21 April 2020. 